\title{
Influence of Organic Material and Biofilms on Disinfectant Efficacy Against Listeria monocytogenes
}

\author{
Hilda Nyati ${ }^{\mathrm{a}, \mathrm{b},{ }^{*}}$, Rijkelt Beumer $^{\mathrm{a}}$, Stijn van Der Veen ${ }^{\mathrm{a}}$, Wilma Hazeleger $^{\mathrm{a}}$, ANd \\ TJAKKO ABEE

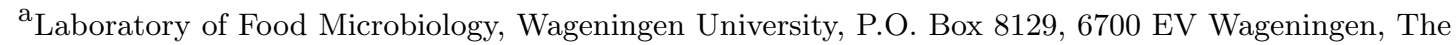 \\ Netherlands \\ ${ }^{\mathrm{b}}$ Department of Applied Biology and Biochemistry, National University of Science and Technology, P.O. Box \\ AC939, Ascot, Bulawayo, Zimbabwe \\ *hnyati@hotmail.com \\ TEL: +2639282842 \\ FAX: +2639286390
}

Received: 16 September 2011; Published online: 18 April 2012

\begin{abstract}
The effects of organic material and biofilm formation on the efficacy of Suma Tab D4 chlorine tablets and Suma Bac D10 quaternary ammonium compound (QAC) against Listeria monocytogenes was determined in suspension and on stainless steel and polystyrene surfaces according to standard disinfectant test methodology. Exposure to 200 and $740 \mathrm{mg} \mathrm{L}^{-1} \mathrm{QAC}$ and to $150 \mathrm{mg} \mathrm{L}^{-1}$ active chlorine resulted in a $>5.0 \log _{10} \mathrm{CFU} \mathrm{mL} \mathrm{m}^{-1}$ and $>5.0 \log _{10} \mathrm{CFU} /$ coupon reduction of six L. monocytogenes strains within one minute, in suspension tests, and on stainless steel surfaces, respectively. Additionally, there was a reduction by as much as $5 \log _{10} \mathrm{CFU} /$ coupon or $5 \log _{10} \mathrm{CFU} /$ well of reference strains EGDe and Scott A biofilms within five minutes on stainless steel and polystyrene surfaces. Organic material, added as bovine serum albumin at $0.3 \%(\mathrm{w} / \mathrm{v})$ completely prevented the inactivation of $L$. monocytogenes in $150 \mathrm{mg} \mathrm{L}^{-1}$ chlorine, while reductions of only $0.6 \pm 0.1 \log _{10} \mathrm{CFU} \mathrm{mL} \mathrm{mL}^{-1}$ were recorded in the presence of UHT milk at $3 \%(\mathrm{v} / \mathrm{v})$. In contrast, reductions of $\geq 5 \log _{10} \mathrm{CFU} \mathrm{mL}^{-1}$ were recorded within one minute on exposure to $740 \mathrm{mg} \mathrm{L}^{-1}$ QAC in the presence of $0.3 \%$ (w/v) bovine serum albumin and within two minutes in the presence of $20 \%$ (v/v) UHT milk. Although Suma D4 chlorine tablets and Suma Bac D10 QAC are effective listericidal agents at recommended concentrations, Suma Tab D4 chlorine efficacy against L. monocytogenes is impaired by the presence of low concentrations of organic material, while Suma Bac D10 QAC maintains its listericidal activity in high organic loads.
\end{abstract}

Keywords: Listeria monocytogenes, chlorine, quaternary ammonium compounds, organic residues, biofilms

\section{Introduction}

The presence of hazardous microorganisms such as Listeria monocytogenes on food-processing equipment emphasises the significance of proper cleaning and sanitizing practices as an aid in preventing contamination of processed foods. To be deemed effective, sanitizing agents must re- duce a given test organism by at least $5 \log _{10}$ $\mathrm{CFU} \mathrm{mL}^{-1}$ or coupon within 5 minutes in suspension and carrier/surface tests (ECS, 2000; Fraise, 2008). However, efficacy is dependent on microbial species and practical conditions such as disinfectant concentration, contact time, organic load, water hardness, $\mathrm{pH}$, presence of biofilms, 
temperature, and presence of protective agents such as lipids (Gebel, Altena A. Vacata, \& Exner, 2005).

The sanitizing agents that are active against a wide range of microorganisms include chlorinebased compounds, quaternary ammonium compounds (QACs), acid sanitizers, ozone, and iodophores (Bessems, 1998; Best, Kennedy, \& Coates, 1990; Mustapha \& Liewen, 1989). Of these, chlorine-based sanitizers and quaternary ammonium compounds are the most commonly used in the food industry. Chlorinated compounds are applied at $50-200 \mathrm{mg} \mathrm{L}^{-1}$ available chlorine at $24^{\circ} \mathrm{C}$ or ambient temperature for at least 2 minutes. The bactericidal activity is attributed to undissociated hypochlorous acid, which diffuses into the bacterium inducing the formation of toxic oxidative species that combine with proteins, leading to the inhibition of oxidative phosphorylation, and damage to nucleic acids and enzymes (Lado \& Yousef, 2007; McDonnell \& Russell, 1999). The mode of action on the other hand, of QACs, which are applied at concentrations of 200 to $800 \mathrm{mg} \mathrm{L}^{-1}$ for at least two minutes, is attributed to reaction with bacterial carboxylic groups resulting in the permealisation of the cytoplasmic membrane, denaturation of essential cell proteins and inactivation of cellular enzymes (Earnshaw \& Lawrence, 1998; McDonnell \& Russell, 1999).

Lopes (1986), Brackett (1987), Mustapha and Liewen (1989), Best et al. (1990) and Aarnisalo et al. (2000) have demonstrated the effectiveness of sodium hypochlorite against $L$. monocytogenes. A $4 \log _{10} \mathrm{CFU} \mathrm{mL}^{-1}$ reduction in planktonic cells by $200 \mathrm{mg} \mathrm{L}^{-1}$ sodium hypochlorite within one minute was reported by Mustapha and Liewen (1989), while $4 \log _{10} \mathrm{CFU} /$ coupon reductions were recorded after 5 minutes on smooth stainless steel surfaces. In the same study, $50 \mathrm{mg} \mathrm{L}^{-1}$ of a QAC (n-alkyl dimethyl dichlorobenzyl ammonium chloride), resulted in $>4 \log _{10}$ reductions in vitro and on smooth and pitted stainless steel surfaces within 5 minutes. Similarly, Luppens (2002) reported a 3.9 $\log _{10} \mathrm{CFU} \mathrm{mL}-1$ reduction of planktonic exponential phase cells of $L$. monocytogenes after a five minute exposure to $25 \mathrm{mg} \mathrm{L}^{-1}$ of the QAC benzalkonium chloride.

Presence of organic material is one of the most significant factors influencing the efficacy of disinfectants against microorganisms. Organic material may interfere with the efficacy of sanitization procedures by either inactivating the disinfectant or blocking it from surface contact. Generally, quaternary ammonium compounds perform better than chlorine sanitizers in the presence of organic matter, although their bactericidal efficacy is reduced to a variable degree depending on the type of organic matter, the kind of quaternary ammonium compound involved, as well as the type of microorganism (Bessems, 1998; Gonzalez-Fandos, Sanz, Garcia-Fernandez, \& Garcia-Arias, 2005; Kawamura-Sato, Wachino, Kondo, Ito, \& Arakawa, 2008).

Biofilm formation also compromises the sanitation of food processing surfaces due to increased microbial resistance, and the subsequent spreading of detached cells to other areas of processing plants. Proposed explanations for the observed resistance in biofilms include low diffusion through the cellular matrix and exopolysaccharides, chemical or enzymatic modification of the antibacterial agent, physiological changes due to slow growth rate and starvation responses, and the induction of attachment specific physiologies (Blackman \& Frank, 1996; Lado \& Yousef, 2007; Moretro \& Langsrud, 2004; Pan, Breidt, \& Kathariou, 2006; Trachoo, 2003). The attachment of L. monocytogenes to stainless steel, glass, rubber and polystyrene surfaces has been described by Kalmokoff et al. (2001).

In view of the significance of $L$. monocytogenes as a food-borne pathogen, and the dependence of effective sanitation on practical conditions and the selection of appropriate sanitizers, the objectives of this study were to determine the efficacy of recently introduced QAC and chlorine formulations against L. monocytogenes in suspension, on stainless steel surfaces, in the presence of organic material, and in biofilms.

\section{Experimental}

\subsection{L. monocytogenes strains and culture conditions}

A total of six L. monocytogenes strains (reference strains EGDe and Scott A, and four food 
isolates Li0010, Li0013, Li0019, Li0025) were selected from the culture collection of the Laboratory of Food Microbiology, Wageningen University, for use in disinfectant tests. Stock cultures for each strain were prepared by mixing $700 \mu \mathrm{L}$ of a 24h Brain Heart Infusion (BHI, BDH) broth culture with $300 \mu \mathrm{L}$ of $87 \%$ glycerol (Sigma), and maintained at $-20^{\circ} \mathrm{C}$ in screw-cap cryovials (Nalge NUNC International, Denmark) for the duration of the study. The cultures were activated before use by transfer to $\mathrm{BHI}$ agar $(\mathrm{BDH})$, and incubated at $30^{\circ} \mathrm{C}$ for $48 \mathrm{~h}$. Single colonies were subsequently used for inoculation into BHI broth and incubated at $37^{\circ} \mathrm{C}$ for $24 \mathrm{~h}$.

\subsection{Preparation of disinfectants}

Suma Bac D10 QAC disinfectant (Johnson Diversey, Utrecht, Netherlands) was used at the recommended concentration of $740 \mathrm{mg} \mathrm{L}^{-1}$ of the active compound alkyl dimethyl benzyl ammonium chloride by diluting $10 \mathrm{~mL}$ of disinfectant in $1 \mathrm{~L}$ of sterile demineralised water. Solutions containing $200 \mathrm{mg} \mathrm{L}^{-1} \mathrm{QAC}$ were prepared by diluting $2.7 \mathrm{~mL}$ of Suma Bac D10 or $0.4 \mathrm{~mL}$ of a $50 \%$ benzalkonium chloride stock solution (Acros organics, New Jersey) in 1L of sterile demineralized water. Chlorine solutions $\left(150 \mathrm{mg} \mathrm{L}^{-1}\right)$ were prepared in compliance with product usage instructions by dissolving one sodium dichloroisocyanurate tablet (Suma Tab D4, Johnson Diversey) in $10 \mathrm{~L}$ of sterile demineralised water. Solutions containing $50 \mathrm{mg} \mathrm{L}^{-1}$ chlorine were prepared by further dilution of $150 \mathrm{mg} \mathrm{L}^{-1}$ solutions.

\subsection{Suspension tests}

Initial counts of the test cultures were determined from $1 \mathrm{~mL}$ tryptone soya agar (TSA, Oxoid) pour-plates after incubation at $30^{\circ} \mathrm{C}$ for $48 \mathrm{~h}$. Suspension tests were carried out according to the standard EN 13727 disinfectant test protocol (ECS, 2000; Fraise, 2008). For each disinfectant, efficacy against L. monocytogenes was determined by adding $0.1 \mathrm{~mL}$ of a $24 \mathrm{~h}$ BHI broth culture to $9.9 \mathrm{~mL}$ of a disinfectant solution at ambient temperature, giving an initial range of $10^{7}$ $10^{8} \mathrm{CFU} \mathrm{mL}{ }^{-1}$, while in control samples the disinfectant was replaced by sterile de-mineralized water. At the end of the required contact time, the disinfectant was inactivated by transferring $1 \mathrm{~mL}$ of the culture suspension to $9 \mathrm{~mL}$ of neutralizer composed of $0.3 \%$ lecithin, $3 \%$ Tween 80 , $0.5 \%$ sodium thiosulphate, $0.1 \%$ L-histidine and phosphate buffer (ECS, 2000). Survivors were enumerated from TSA pour plates incubated at $30^{\circ} \mathrm{C}$ for $48 \mathrm{~h}$. All tests were carried out in triplicate.

\subsection{Surface tests}

For surface tests, $10 \mu \mathrm{L}$ of a $24 \mathrm{~h}$ BHI broth culture was placed on each $1.9 \mathrm{~cm}^{2}$ stainless steel coupon (Type 304, Wageningen University, Netherlands), giving an initial range of $10^{6} 10^{7}$ $\mathrm{CFU} /$ coupon, and allowed to air-dry for $1 \mathrm{~h}$ in a class II biological safety cabinet (Bloomfield et al., 1994). The coupons were then placed in culture plate wells (Greiner bio-one) and covered with $1 \mathrm{~mL}$ of disinfectant. After the required contact time, each coupon was transferred aseptically to $10 \mathrm{~mL}$ of neutralizer containing about $4.5 \mathrm{~g}$ of $1 \mathrm{~mm}$ diameter glass beads (Emergo, Landsmeer, Netherlands). Cells were subsequently dislodged from stainless steel surfaces by vortexing for 30 seconds, and survivors enumerated using TSA pour plates. Initial counts on coupons after drying were determined by dislodging cells into $10 \mathrm{~mL}$ of neutralized bacteriological peptone (Oxoid) through bead vortexing, and subsequent enumeration in TSA pour plates.

\subsection{Bovine serum albumin tests}

The bovine serum albumin (BSA) solution used to simulate clean conditions was prepared by dissolving $0.3 \mathrm{~g}$ of BSA in $100 \mathrm{~mL}$ of demineralised water and sterilized by membrane filtration. A further ten-fold dilution gave a final concentration of $0.03 \%$ in disinfectant solutions. In tests that simulated dirty conditions the final concentration of BSA and washed sheep erythrocytes in disinfectants were $0.3 \%(\mathrm{w} / \mathrm{v})$ and $0.3 \%(\mathrm{v} / \mathrm{v})$, respectively (ECS, 2000). 


\subsection{Disinfectant tests in the presence of UHT milk}

Whole UHT milk (3\% fat content) was added to $50 \mathrm{mg} \mathrm{L}^{-1}$ and $150 \mathrm{mg} \mathrm{L}^{-1}$ Suma Tab D4 chlorine, and to $200 \mathrm{mg} \mathrm{L}^{-1}$ and $740 \mathrm{mg} \mathrm{L}^{-1}$ Suma Bac D10 QAC to give a final concentration of 1 - 50\% UHT milk (v/v) in disinfectant solutions before use in suspension and surface tests.

\subsection{Disinfectant tests on stainless steel biofilms}

L. monocytogenes biofilms on stainless steel surfaces (Figure 1a) were prepared by placing sterile stainless steel coupons $\left(1.9 \mathrm{~cm}^{2}\right)$ in $50 \mathrm{~mL}$ centrifuge tubes containing $3 \mathrm{~mL}$ of sterile BHI broth. Each tube was inoculated with $30 \mu \mathrm{L}$ of a $24 \mathrm{~h} \mathrm{BHI}$ broth culture and incubated at $20^{\circ} \mathrm{C}$ for 48 or $72 \mathrm{~h}$. Prior to disinfectant tests, the stainless steel coupons were rinsed three times with sterile demineralized water for the removal of unattached cells. Each coupon was then placed in a culture plate well and covered with $1 \mathrm{~mL}$ of disinfectant for 1 to 5 minutes. After the required contact time coupons were transferred to $10 \mathrm{~mL}$ of neutralizer containing $4.5 \mathrm{~g}$ of $1 \mathrm{~mm}$ diameter beads, and the attached cells dislodged by vortexing for 1 minute. Viable cells were enumerated using TSA pour plates.

\subsection{Disinfectant tests on polystyrene biofilms}

Polystyrene 12-well culture plates (Greiner bioone, Netherlands) containing $1 \mathrm{~mL}$ of BHI broth in each well were inoculated with $10 \mu \mathrm{L}$ of a $24 \mathrm{~h}$ BHI broth culture and incubated at $20^{\circ} \mathrm{C}$ for $48 \mathrm{~h}$. Growth medium was discarded from culture wells by inverting the plates, and non-adherent cells removed by washing three times with sterile demineralized water. Disinfectant $(1 \mathrm{~mL})$ was added to each well and $3 \mathrm{~mL}$ of neutralizer added after 1 or 5 minutes of exposure to the disinfectant. Biofilms (Figure 1b) were then detached from culture plates by pipetting the medium up and down several times before transferring the entire contents of the well to an additional $6 \mathrm{~mL}$ of neutralizer. Viable cells were enumerated after serial dilution using $1 \mathrm{~mL}$ TSA pour-plates. The absence of clumps in biofilm suspensions was confirmed by microscopic examination.

\section{Results and Discussion}

\subsection{Effectiveness of chlorine and QACs against $L$. monocytogenes in suspension tests}

For all six L. monocytogenes strains under study, $>5 \log _{10} \mathrm{CFU} \mathrm{mg} \mathrm{L}{ }^{-1}$ reductions in suspended cells were recorded within one minute in 150 $\mathrm{mg} \mathrm{\textrm {L } ^ { - 1 }}$ chlorine. A $5 \log _{10}$ reduction was also achieved within one minute in $50 \mathrm{mg} \mathrm{L}^{-1}$ chlorine for five strains, while $4.3 \pm 0.2 \log _{10}$ reductions were recorded for strain Li0019 (Table 1). Similarly, five log reductions in cell suspensions were achieved within one minute in $200 \mathrm{mg} \mathrm{L}^{-1}$ or $740 \mathrm{mg} \mathrm{L}{ }^{-1}$ Suma-Bac D10 QAC and $200 \mathrm{mg}$ $\mathrm{L}^{-1}$ benzalkonium chloride (Table 2 ). The observations are consistent with reports by Best et al. (1990) and Gonzalez-Fandos et al. (2005) where $>5 \log _{10} \mathrm{CFU} \mathrm{mg} \mathrm{L} \mathrm{L}^{-1}$ reductions in suspension tests were observed within 1-5 minutes at the lowest recommended QAC concentrations.

\subsection{Efficacy of chlorine and QACs against $L$. monocytogenes on stainless steel surfaces}

Suma Bac D10 QAC was equally effective against L. monocytogenes on stainless steel surfaces, resulting in five $\log _{10} \mathrm{CFU} /$ coupon reductions within one minute of exposure to $200 \mathrm{mg} \mathrm{L}^{-1}$ and $740 \mathrm{mg} \mathrm{L}^{-1}$ solutions. For Suma Tab D4, although five $\log _{10}$ reductions were recorded within one minute of exposure to $150 \mathrm{mg} \mathrm{L}^{-1}$ chlorine, five minutes was required for a five $\log$ kill in $50 \mathrm{mg} \mathrm{L}{ }^{-1}$ chlorine on stainless steel surfaces. The higher resistance to chlorine disinfectants observed in surface tests may be due to the protection of cells in inner layers by those on surface layers or the initiation of stress responses as suggested by Hill, Cotter, Sleator, and Gahan 

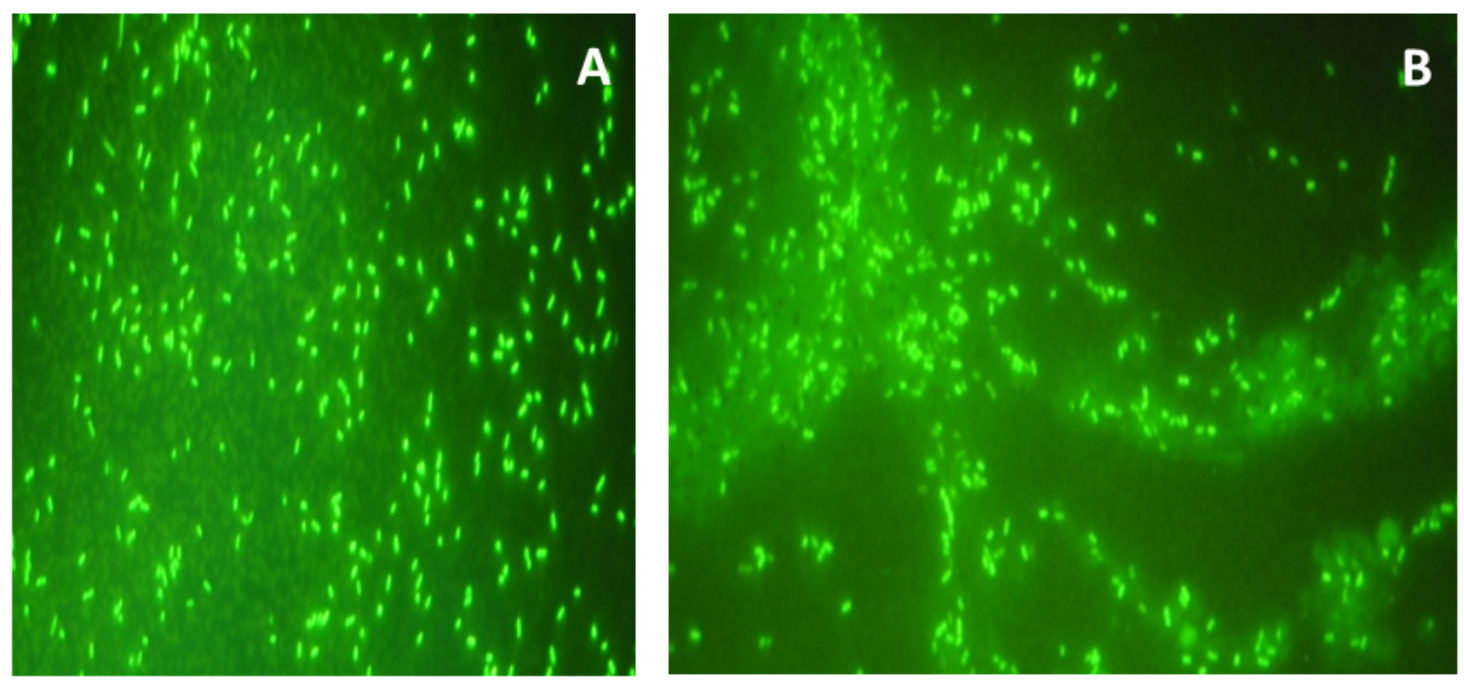

Figure 1: L. monocytogenes (EGDe) 48h biofilm on stainless steel (A) and on Polystyrene (B).

Table 1: Efficacy of Suma Tab D4 chlorine against L. monocytogenes in suspension tests.*

\begin{tabular}{lcc}
\hline Strain & \multicolumn{2}{c}{$\log _{10}$ reduction $\left(\mathrm{CFU} \mathrm{mg} \mathrm{L} \mathrm{m}^{-1}\right.$ ) in $1 \mathrm{~min}$} \\
\cline { 2 - 3 } & $50 \mathrm{mg} L^{-1}$ chlorine & $150 \mathrm{mg} L^{-1}$ chlorine \\
\hline EGDe (serotype 1/2a) & $>5.0$ & $>5.0$ \\
Scott A (serotype 4b) & $>6.4$ & $>6.4$ \\
Li0010 (from goose liver pate) & $>6.4$ & $>6.4$ \\
Li0013 (nisin resistant) & $5.4 \pm 0.3$ & $>6.4$ \\
Li0019 (nisin resistant) & $4.3 \pm 0.2$ & $>6.1$ \\
Li0025 (nisin resistant) & $>5.6$ & $>5.6$ \\
\hline
\end{tabular}

${ }^{*}$ Results are mean of triplicate samples.

(2002) and Kastbjerg, Nielsen, Arneborg, and Gram (2009).

\subsection{Effect of BSA on the efficacy of chlorine and QACs against L. monocytogenes}

The antimicrobial activity of $150 \mathrm{mg} \mathrm{L}^{-1}$ Suma D4 chlorine was inhibited by the presence of $0.3 \%$ $\mathrm{BSA}$, resulting in a $0-0.6 \log _{10} \mathrm{CFU} \mathrm{mg} \mathrm{L} \mathrm{L}^{-1}$ reduction of suspended cells after five minutes, compared to the $5 \log$ reduction within 1 minute in the absence of organic material. This may be explained by the fact that chlorine bactericidal activity is based on its reaction with proteins and enzymes (Lado \& Yousef, 2007; McDonnell \& Russell, 1999). It is conceivable that pre-exposure to bovine serum albumin results in chlorine reacting with extraneous protein instead of the microbial targets, thus preventing microbial inactivation. In contrast, the efficacy of $200 \mathrm{mg} \mathrm{L}^{-1}$ or $740 \mathrm{mg} \mathrm{L}^{-1}$ Suma Bac D10 QAC against $L$. monocytogenes was not impaired by the presence of $0.3 \% \mathrm{BSA}$, a concentration that is representative of high organic loads. 
Disinfectant Efficacy Against Listeria monocytogenes $\mid 81$

Table 2: Efficacy of quaternary ammonium compounds against L. monocytogenes in suspension tests.*

\begin{tabular}{lccc}
\hline Strain & \multicolumn{3}{c}{$\log _{10}$ reduction $\left(\mathrm{CFU} \mathrm{mg} \mathrm{L}^{-1}\right)$ in $1 \mathrm{~min}$} \\
\cline { 2 - 4 } & $200 \mathrm{mg} \mathrm{L} L^{-1}$ & $740 \mathrm{mg} L^{-1}$ & $200 \mathrm{mg} \mathrm{L} L^{-1}$ \\
\hline & Suma Bac D10 & Suma Bac D10 & Benzalkonium chloride \\
EGDe & $>5.0$ & $>5.0$ & $>5.1$ \\
Scott A & $>6.4$ & $>6.4$ & $>6.6$ \\
Li0010 & $>6.3$ & $>6.3$ & $>6.5$ \\
Li0013 & $>6.5$ & $>6.5$ & $>6.6$ \\
Li0019 & $>6.2$ & $>6.2$ & $>6.5$ \\
Li0025 & $>5.7$ & $>5.7$ & $>6.0$ \\
\hline
\end{tabular}

\subsection{Effect of UHT milk on Suma Tab D4 and Suma Bac D10 QAC efficacy}

The sensitivity of chlorine disinfectants to organic debris was confirmed by the inhibition of $150 \mathrm{mg} \mathrm{L}^{-1}$ Suma D4 chlorine in $3 \%$ UHT milk, resulting only in a $0.6 \pm 0.2 \log _{10} \mathrm{CFU} \mathrm{mg} \mathrm{L}^{-1}$ reduction of $L$. monocytogenes (EGDe) after a five minute exposure in suspension (Figure 2). Suma Bac D10 QAC (740mg L $\left.{ }^{-1}\right)$ was less sensitive to milk residues than Suma D4 chlorine, and achieved $5 \log$ reductions in L. monocytogenes suspensions within two minutes in $20 \%$ UHT milk (Figure 3). The stability of the QAC in the presence of milk residues is consistent with observations from bovine serum albumin tests. However, in $30 \%$ UHT, $740 \mathrm{mg} \mathrm{L}^{-1}$ Suma Bac D10 QAC required a 10 minute exposure for a 5 log reduction in suspension tests.

Reduction of QAC concentration resulted in greater sensitivity to the presence of milk residues in suspension tests, as shown by the requirement for a ten-minute exposure for a 5 log kill in $10 \%$ UHT milk for $200 \mathrm{mg} \mathrm{L}^{-1}$ Suma Bac D10 compared to the one minute required in $10 \%$ UHT milk for $740 \mathrm{mg} \mathrm{L}^{-1}$ QAC. Use of the highest recommended disinfectant concentration is therefore critical for the maintenance of disinfectant efficacy in the presence of organic material.

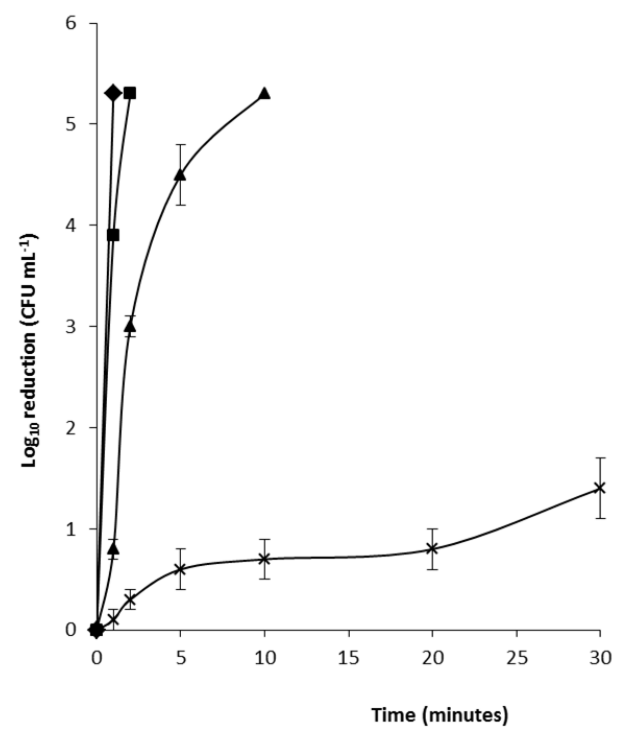

Figure 2: Effect of UHT milk $\left(\begin{array}{l}\bullet \\ \mathbf{n}\end{array}\right.$ $2 \%, \times 3 \%$ ) on the efficacy of $150 \mathrm{mgL}^{-1}$ Suma Tab D4 chlorine against Listeria monocytogenes (EGDe) in suspension tests.

\subsection{Effectiveness of chlorine and QACs against $\boldsymbol{L}$. monocytogenes biofilms}

Five $\log$ reductions of $48 \mathrm{~h}$ and $72 \mathrm{~h}$ SS and PS EGDe and Scott A biofilms were recorded within one minute in $150 \mathrm{mg} \mathrm{L}^{-1}$ chlorine and $740 \mathrm{mg}$ $\mathrm{L}^{-1}$ QAC (see Figures 4 and 5). In a similar study, Ronner and Wong (1993) reported 3-5 $\log _{10} \mathrm{CFU} /$ coupon reductions of L. monocytogenes biofilms on application of $200 \mathrm{mg} \mathrm{L}^{-1} \mathrm{QAC}$ and $100 \mathrm{mg} \mathrm{L}^{-1}$ chlorine for 1 and 2 minutes, 


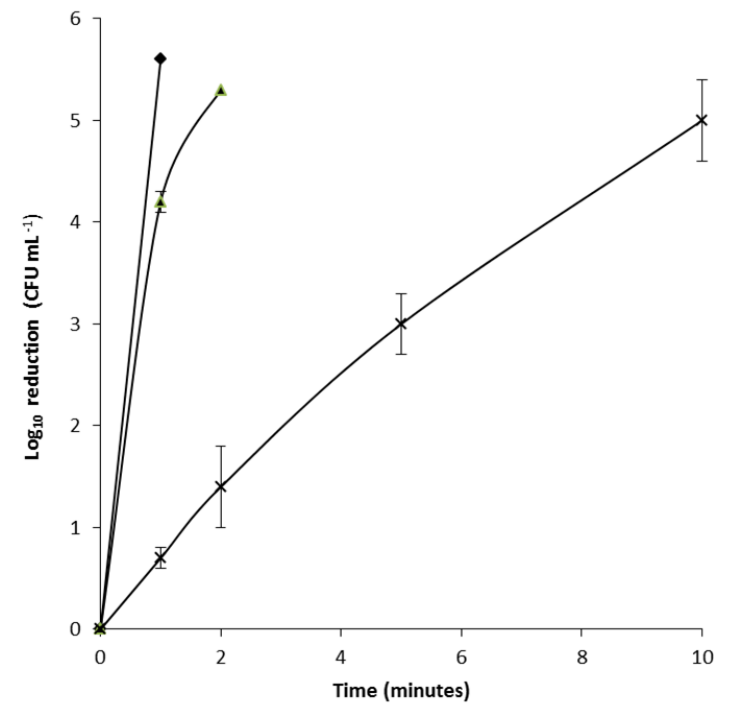

Figure 3: Effect of UHT milk ( $10 \%, \boldsymbol{\Delta} 20 \%$, $\times 30 \%$ ) on the efficacy of $740 \mathrm{mgL}^{-1}$ Suma Bac D10 QAC against Listeria monocytogenes (EGDe) in suspension tests.

respectively. The susceptibility of $L$. monocytogenes biofilms to disinfectants may be explained by its attachment as single cell layers on stainless steel surfaces and the production of loosely attached biofilms on polystyrene, which resullt in the exposure of cell surfaces to antimicrobials.

Although a five log reduction in $48 \mathrm{~h}$ biofilms was achieved within five minutes on application of $200 \mathrm{mg} \mathrm{L}^{-1} \mathrm{QAC}$, only $3.5 \pm 0.1 \log _{10}$ reductions were recorded for $72 \mathrm{~h}$ Scott A biofilms, suggesting an increase in resistance with aging. Increased biofilm resistance by up to two logs on aging has also been reported by Sommer, MartinRouas, and Mettler (1999).

\section{Conclusion}

Suma Tab D4 chlorine tablets and Suma Bac D10 QAC are effective listericidal agents when applied at the recommended concentrations, achieving the required five log reduction within 1-5 minutes in planktonic cells, on stainless steel surfaces, and in biofilms. However, Suma Tab D4 is inactivated in the presence of low concentrations of organic material, while Suma Bac D10

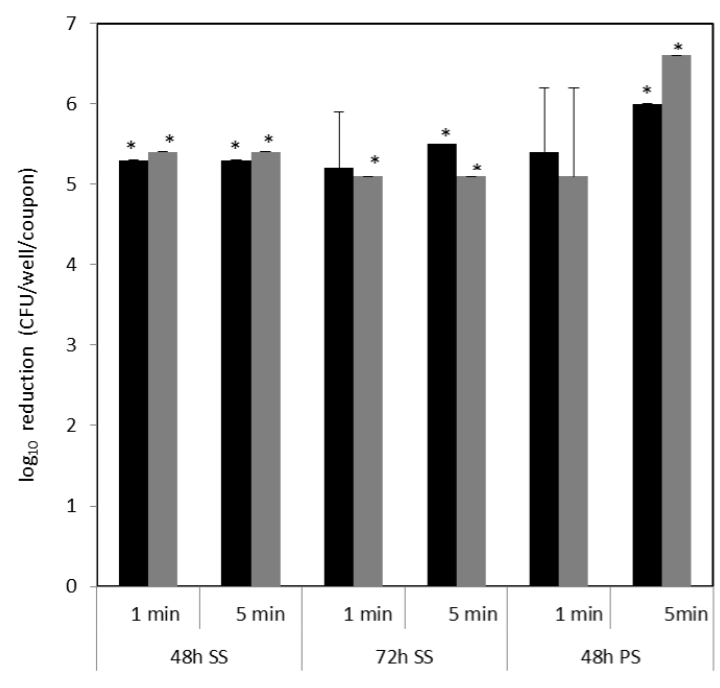

Figure 4: Susceptibility of L. monocytogenes

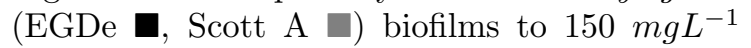
Suma TabD4 chlorine. * residual counts below detection levels. SS (stainless steel surfaces), PS (Polystyrene surfaces).

QAC maintains its anti-microbial activity in the presence of high levels of organic residues.

\section{Acknowledgements}

The authors would like to thank the Netherlands Fellowship Programme and the Laboratory of Food Microbiology (Wageningen University), for technical and financial support.

\section{References}

Aarnisalo, K., Salo, S., Miettmen, H., Suihko, M., Wirtanen, G., Autio, T., ... Sjoberg, A. M. (2000). Bactericidal efficiencies of commercial disinfectants against Listeria monocytogenes on surfaces. Journal of Food Safety, 20(4), 237-250. doi:10.1111/j.1745-4565. 2000.tb00302.x

Bessems, E. (1998, April). The effect of practical conditions on the efficacy of disinfectants. International Biodeterioration $\&$ 


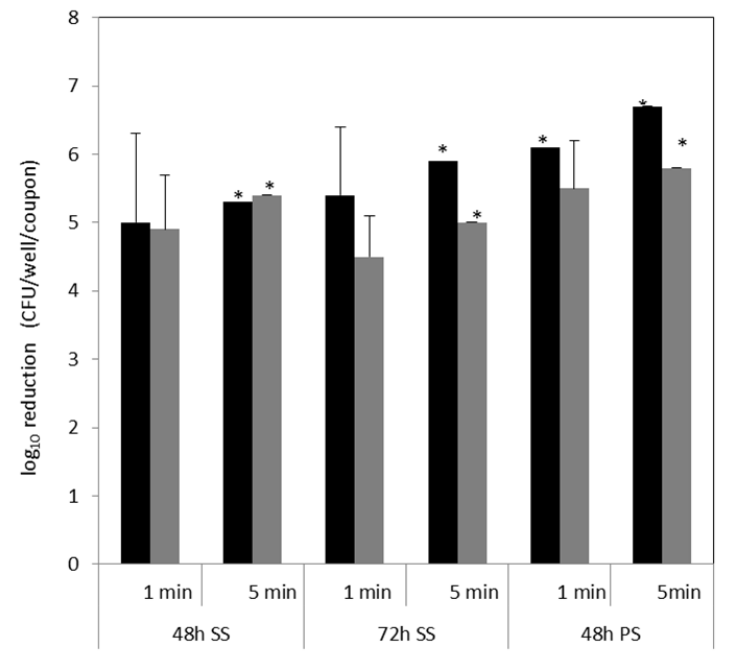

Figure 5: Susceptibility of L. monocytogenes (EGDe $\square$, Scott A $\square$ ) biofilms to $740 \mathrm{mgL}^{-1}$ Suma Bac D10 QAC. * residual counts below detection levels. SS (stainless steel surfaces), PS (Polystyrene surfaces).

Biodegradation, 41(3-4), 177-183. doi:10 . 1016/S0964-8305(98)00022-5

Best, M., Kennedy, M. E., \& Coates, F. (1990, February). Efficacy of a variety of disinfectants against listeria spp. Applied and Environmental Microbiology, 56(2), 377-380.

Blackman, I. C., \& Frank, J. F. (1996, August). Growth of Listeria monocytogenes as a biofilm on various food-processing surfaces. Journal of Food Protection, 59(8), 827-831.

Bloomfield, S. F., Arthur, M., Van Klingerenl, B., Pullen, W., Holah, J. T., \& Elton, R. (1994, January). An evaluation of the repeatability and reproducibility of a surface test for the activity of disinfectants. Journal of Applied Bacteriology, 76(1), 86-94. doi:10.1111/j.1365-2672.1994.tb04420.x

Brackett, R. (1987, December). Antimicrobial effect of chlorine on Listeria monocytogenes. Journal of Food Protection, 50(12), 9991003.

Earnshaw, A. M., \& Lawrence, L. M. (1998, April). Sensitivity to commercial disinfectants, and the occurrence of plas- mids within various Listeria monocytogenes genotypes isolated from poultry products and the poultry processing environment. Journal of Applied Microbiology, 84(4), 642-648. doi:10.1046/j.1365-2672. 1998.00395.x

ECS. (2000). European standard en 1372\%: chemical disinfectants - quantitative suspension test for evaluation of bactericidal activity for instruments used in the medical area.

Fraise, A. P. (2008, October). European norms for disinfection testing. Journal of Hospital Infection, 70, 8-10. doi:10.1016/S01956701(08)60004-3

Gebel, J., Altena A., K., Vacata, V., \& Exner, M. (2005). Directory of microbicides for the protection of materials. In W. Paulus (Ed.), (Chap. Disinfectants and sanitizers, pp. 305-315). Dordrecht, Springer.

Gonzalez-Fandos, E., Sanz, J., GarciaFernandez, M. C., \& Garcia-Arias, M. T. (2005, September). Effectiveness of disinfectants used in the food industry on microorganisms of sanitary interest. Acta Alimentaria, 34(3), 253-258. doi:10.1556/AAlim.34.2005.3.7

Hill, C., Cotter, P. D., Sleator, R. D., \& Gahan, C. G. M. (2002). Bacterial stress response in Listeria monocytogenes: jumping the hurdles imposed by minimal processing. International Dairy Journal, 12(2-3), PII S0958-6946(01)00125-X.

Kalmokoff, M. L., Austin, J. W., Wan, X. D., Sanders, G., Banerjee, S., \& Farber, J. M. (2001, October). Adsorption, attachment and biofilm formation among isolates of Listeria monocytogenes using model conditions. Journal of Applied Microbiology, 91(4), 725-734. doi:10.1046/j.1365-2672. 2001.01419.x

Kastbjerg, V. G., Nielsen, D. S., Arneborg, N., \& Gram, L. (2009, July). Response of Listeria monocytogenes to disinfection stress at the single-cell and population levels as monitored by intracellular ph measurements and viable-cell counts. Applied and Environmental Microbiology, 75(13), 4550-4556. doi:10.1128/AEM.02625-08

Kawamura-Sato, K., Wachino, J.-i., Kondo, T., Ito, H., \& Arakawa, Y. (2008, March). 
Reduction of disinfectant bactericidal activities in clinically isolated acinetobacter species in the presence of organic material. Journal of Antimicrobial Chemotherapy, 61(3), 568-576. doi:10.1093/ jac/ dkm498

Lado, B. H., \& Yousef, A. E. (2007). Characteristics of Listeria monocytogenes important to food processors. In E. Ryser \& M. E.H. (Eds.), Listeria, Listeriosis and Food Safety (pp. 157 -214). Boca Raton, CRC Press.

Lopes, J. A. (1986, November). Evaluation of dairy and food plant sanitizers against - Salmonella-typhimurium and Listeria monocytogenes. Journal of Dairy Science, 69(11), 2791-2796.

Luppens, S. (2002). Suspensions or biofilms: and other factors that affect disinfectant testing on pathogens. (Doctoral dissertation, Wageningen University).

McDonnell, G., \& Russell, A. D. (1999, January). Antiseptics and disinfectants: activity, action, and resistance. Clinical Microbiology Reviews, 12(1), 147-149.

Moretro, T., \& Langsrud, S. (2004). Listeria monocytogenes biofilm formation and persistence in food processing environments. Biofilms, 1, 107-121.

Mustapha, A., \& Liewen, M. (1989, May). Destruction of Listeria monocytogenes by sodium-hypochlorite and quaternary ammonium sanitizers. Journal of Food Protection, 52(5), 306-311.

Pan, Y., Breidt, J., F., \& Kathariou, S. (2006, December). Resistance of Listeria monocytogenes biofilms to sanitizing agents in a simulated food processing environment. Applied and Environmental Microbiology, 72(12), 7711-7717. doi:10 . 1128 / AEM . 01065-06

Ronner, A. B., \& Wong, A. C. L. (1993, September). Biofilm development and sanitizer inactivation of Listeria monocytogenes and Salmonella-typhimurium on stainless-steel and buna-n rubber. Journal of Food Protection, 56(9), 750-758.

Sommer, P., Martin-Rouas, C., \& Mettler, E. (1999, October). Influence of the adherent population level on biofilm population, structure and resistance to chlorination. Food Microbiology, 16(5), 503-515. doi:10. 1006/fmic.1999.0267

Trachoo, N. (2003). Biofilms and the food industry. Songklanakarin Journal of Science and Technology, 25, 807-815. 